Journal homepage: www.aesacademy.org

\title{
A case study of medicinal plants and their usage by the local community of Dilasaini Gaunpalika, Baitadi district, Nepal
}

\author{
Sandesh Thapa* (D) , Sara Rawal, Anuska Prasai, Janak Adhikari, Sarika Bist and Anup Ghimire \\ Gokuleshwor Agriculture and Animal Science College, Baitadi, NEPAL \\ "Corresponding author's E-mail: sand.thapa.2056@gmail.com
}

\section{ARTICLE HISTORY}

Received: 31 October 2020

Revised received: 24 February 2020

Accepted: 13 March 2020

\section{Keywords}

Ayurvedalaya

Ethnomedicinal plants

False daisy

Respondents

Satisfaction

\section{ABSTRACT}

An Ethnomedicinal survey study was conducted to get information about the usage of medicinal plants and the diversity of species found around the village. The main objective of the study was to document the plants for their medicinal and other uses. Ethnomedicinal plants are locally available used by tribal communities and local inhabitants for various medicinal purposes. Random sampling survey was conducted by selecting 50 households to access the medicinal plants and document their usage in Gokuleshwor, Baitadi. A total of 33 species of medicinal plants to treat 40 ailments was reported with their multipurpose use. During the survey, an equal proportion of males and females aged 14 to 78 were selected randomly. The literacy rate of the study area was $80 \%$ and $94 \%$ of the people were found to be involved in the collection of medicinal plants. The majority of the respondents (92\%) used medicinal plants for minor diseases like cuts, wounds whereas few were found to use the medicinal plant for a long time to treat major diseases like cancer, tumor. The use of medicinal plants for skin infections, cuts and wounds, fever was found to be high followed by diarrhea, common cold, ulcer, asthma, jaundice, burns, piles, and eye inflammation. Most of the plants were found to be used for more than one disease. The conservation of Indigenous knowledge on the Ethnomedicinal plant should be promoted as most of the respondents were unaware of the conservation of medicinal plants.

(C)2020 Agriculture and Environmental Science Academy

Citation of this article: Thapa, S., Rawal, S., Prasai, A., Adhikari, J., Bist, S. and Ghimire, A. (2020). A case study of medicinal plants and their usage by the local community of Dilasaini Gaunpalika, Baitadi district, Nepal. Archives of Agriculture and Environmental Science, 5(1): 50-54, https://dx.doi.org/10.26832/24566632.2020.050107

\section{INTRODUCTION}

Nepal is naturally and biologically enriched with diversification. Nepal is ranked $25^{\text {th }}$ and 11 th position in biodiversity richness in the world and Asia respectively. Nepal occupies about $0.1 \%$ of the global area, but harbor $3.2 \%$ and $1.1 \%$ of the world's known flora and fauna. A total of 118 different ecosystems have been identified in Nepal (MoAD, 2017). From Nepal over 300 taxa of MAPs are traded with a total amount of 10,770 tonnes value worth of USD 60.09 million (Ghimire et al., 2016). The geographically important areas of Nepal include Nawalparasi, Chitwan, Bardiya, Kaski, Syangja, Illam, Lamjung, Humla, Jumla, Manang, Mustang, Solukhumbhu, Nuwakot (MoAD, 2017).

The use of medicinal plants for the purpose of curing human diseases and disorders has had a long history. Popular observation on the use and efficiency of medicinal plants significantly contribute to the disclosure of their therapeutic properties, so that they are frequently prescribed, even if their chemical constituents are not always completely known (Maciel et al., 2002). Various national, as well as international research organizations, are involved in order to evaluate and authenticate the medicinal and scientific value of plants (Manandhar, 2002). Over the centuries, the knowledge of their medicinal value and healing properties has been transmitted within and among human communities (Silva et al., 2010). The tribal communities, significantly the women are involved in the continuation, preservation as well as the promotion of the local crop species, collecting and using the forest-based plants in daily dietary and 
medicine. Chiuri is used by the tribal communities for various purpose, highlighting its medicinal importance (Thapa, 2019). Medicinal plants available in different niches are reported by several researchers. Pandey (1961) reported 73 medicinal plants for the first time in Nepal. 143 species of commercial MAPS were assessed from the gradient of Himalayas (Bhattarai and Ghimire, 2006), 51 species were reported from Palpa district which was climbing plants (Singh and Kumar, 2017). Medicinal plant reported from different districts of Nepal; 161 species were reported to use by Tamang community in Makwanpur district (Luitel et al., 2014), Tharu community of Rupandehi district used 45 species of 32 families and 41 genera (Acharya and Acharya, 2009), Magar community of Gulmi district used 161 species of plant for medicinal purpose (Acharya, 2012), 64 plant species were reported from Jhapa district used by Meche people (Rai, 2004), 105 vascular plants of medicinal importance was reported from Terhathum district (Rai, 2003). Nepal is considered to be reservoirs of medicinal plants and trade history from 2005 to 2014 showed an increase of, 27.49 million in 2005 to USD 60.09 million in 2014 (mean for the last 10 years being USD 39.34 million (Ghimire et al., 2016). IUCN has banned 11 species of medicinal plants on their export, collection, and transportation as they are threatened species (IUCN, 2000). Baitadi district is one of the under-developed districts in province 7 as well in the country. Peoples are found to be highly dependent on traditional medicines. Thus, the plant species used by them and their usage in the daily life of people living there have been focused on the study. The main objective of the study is to study the attitude of people's perception towards the medicinal plants and the diversity of species used by the peoples found locally in the home gardens and fields.

\section{MATERIALS AND METHODS}

\section{Study area}

Dilasaini gaunpalika, Baitadi is a hilly district, falls in the province no. 7 of Nepal touching Jhulaghat, India to its border of Nepal. Gokuleshwor village is at an altitude of 800-950 masl (Figure 1). Two wards were selected for study viz. Ward no. 5

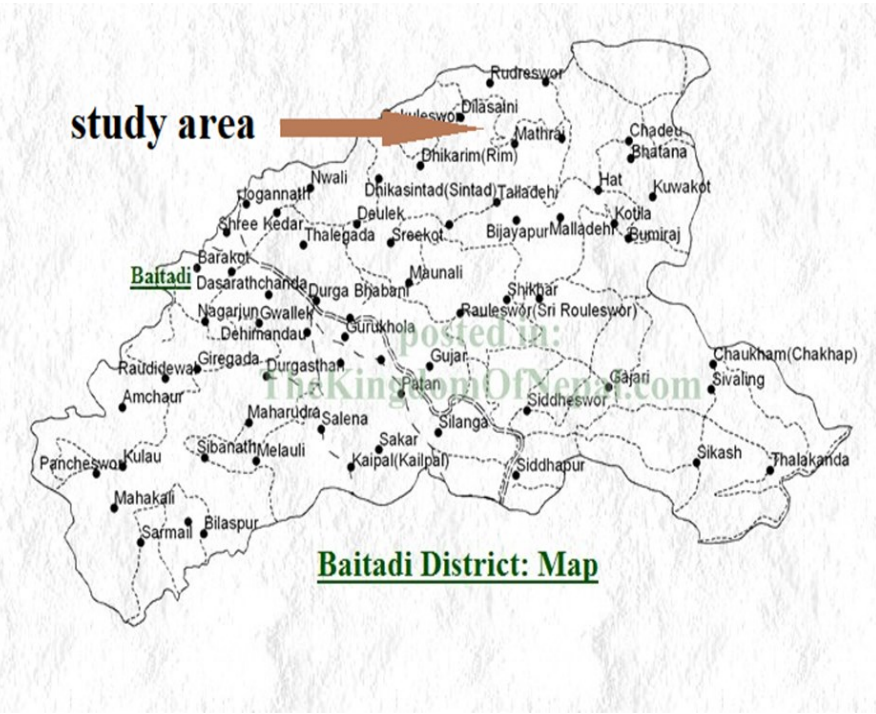

Figure 1. Map of Baitadi district. and ward no. 6. Dilasaini gaunpalika consists of a diversity of plants and among them, the plants used for the medicinal purpose by the peoples are found to be very limited. Thus, the plants used by the peoples were surveyed along with primary information and other information associated with the use of medicinal plants.

\section{Research design and data collection}

The total number of households in Dilasaini VDC is 497 (Source: Dilasaini gaunpalika). Sample size of 50 Households were selected from Dilasaini VDC on simple random basis as sampling frame size was determined (497). The sample size was adjusted to $10 \%$ as suggested by Ajayi et al. (2005) in social sciences research. A questionnaire survey was conducted and a random sampling survey was conducted to collect the information on the use of medicinal plants in Dilasaini gaunpalika. A random sampling survey was conducted and household respondents were interviewed. Also, a group discussion was conducted to gather information about the plant species used by them for the medicinal purpose along with their other uses. For identification of species and medicinal uses literature was cited (Kunwar et al., 2009; Kunwar et al., 2010; Rajbhandari et al., 1995). Also, secondary information was obtained from the conference papers, bulletins and, websites.

\section{Data analysis}

MS Excel 2013 and IBM Statistical Package for the Social Sciences (SPSS) for descriptive analysis. Graphs are prepared through MS Excel 2013.

\section{RESULTS AND DISCUSSION}

Socio-economic characteristics

A total of 50 households were selected randomly for the study out of which $50 \%$ were males and $50 \%$ were females, aged between 14 to 78 . The literacy rate of the area was $80 \%$ and $20 \%$ were found to be illiterate. Agriculture as the primary occupation is found to be of $86 \%$ respondents and $14 \%$ were found to be involved in agriculture as a part time job. None of the respondents were found to get training on the use and protection of medicinal plants (Field survey, 2019).

\section{Usage of medicinal plants}

All of the respondents were found to be involved in the usage of medicinal plants. The easy availability of medicinal plants got an advantage for the use. $94 \%$ of the respondents were found to use medicinal plants occasionally whereas $6 \%$ were found to use it regularly. Not all of the respondents were found to have a positive response regarding satisfaction gained from it. About $92 \%$ of the respondents are satisfied by the use of it whereas $8 \%$ of them are not satisfied with the use of it, Figure 2 (Field survey, 2019).

\section{Marketing and preference of medicinal plants}

Only $2 \%$ of the respondent was found to be involved in the marketing of medicinal plants whereas $98 \%$ do not involve in it. 


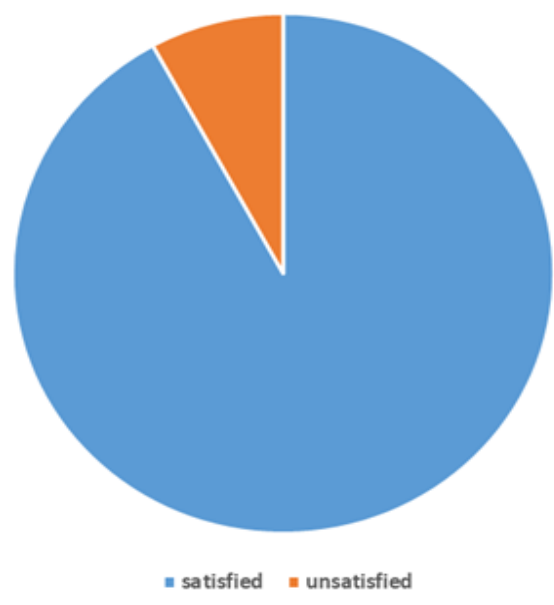

Figure 2. The satisfaction gained from its use.

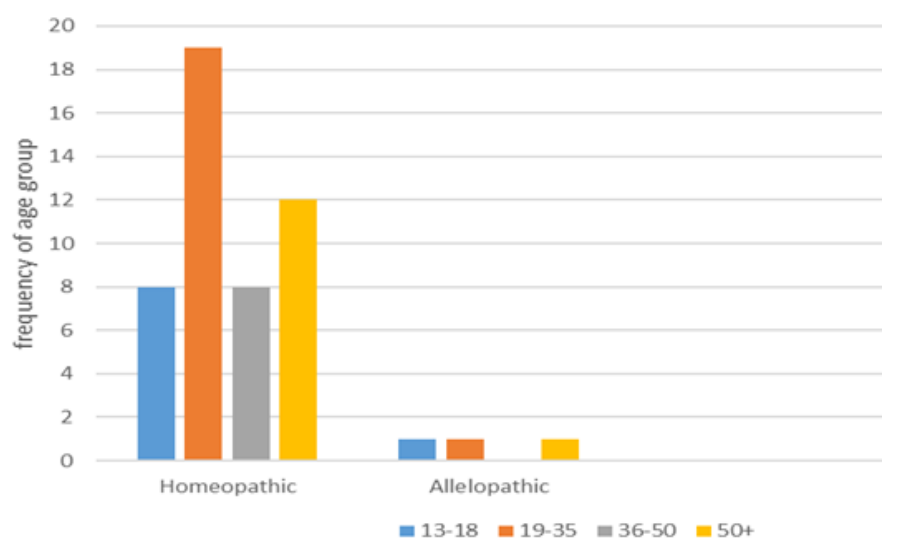

Figure 3. Preference to medicinal plants with age.

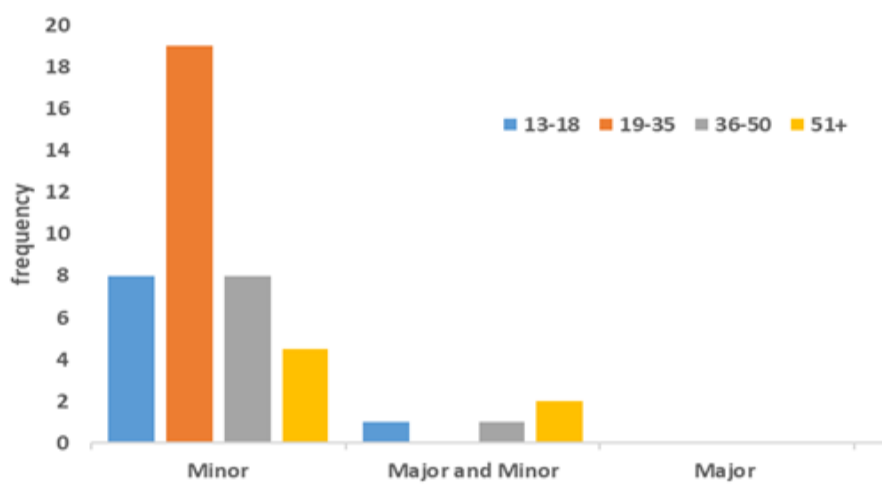

Figure 4. Use of medicinal plants in different situations.

The response regarding the preference to medicinal plants overprocessed medicine was found to be $94 \%$ and $6 \%$ of them are attracted to processed medicine. A cross tab result regarding the preference to medicinal plants towards age showed a result which is presented in the Figure 3.

\section{Condition to prefer}

The study was conducted among respondents of different age groups randomly. The majority of them were found to use for minor diseases like cuts, burns, wounds, fever, and common cold. However, those who were found to use for major diseases were also found to use for minor diseases. A study report shows that $92 \%$ were found to use the medicinal plant for minor diseases and $8 \%$ were found to use for major diseases like typhoid, jaundice, tuberculosis, asthma, heart pain, etc. None of
The respondents were found to use for major diseases only (Figure 4).

Diversity of medicinal plants investigated with their related information

Medicinal plants documented in the study were found to be used for curing of 40 ailments. The majority of the plant species were found to have ma multipurpose use for both medicinal and other various culinary uses. The majority of plant species were found to be used for skin infection, diarrhea, fever, common cold, cough, cuts and burns, asthma. However, diseases like heart pain, spleen enlargement, tumor, cancer, ulcer, astringent, fungal infection, weakness, eye inflammation, dandruff, jaundice, piles, gastritis were found to be cured by a few species. The details of the medicinal plant with their medicinal uses documented from the study are as shown in Table 1.

Medicinal plants assessed in the study were found to have multipurpose use including ornamental and food value. About 34 species were reported which was continuously used from generation to generation for the curing of 41 ailments. A similar use of plants for the medicinal purpose was reported by Kunwar et al. (2010) in far-west Nepal. The author reported 48 species of medicinal plants used for curing various ailments like asthma, tumor, diabetes, cold and cough, joint pain, gastritis and many more. The multipurpose use of medicinal plants was reported by Rokaya et al. (2010) with their culinary and ornamental uses. The author also reported that the medicinal plants were used chiefly for ophthalmic and gastrointestinal ailment. Similarly, Joshi et al., (2019) reported 44 medicinal plants for treating 62 ailments from Gyaneshwor community forest of Chitwan, moreover, Uprety et al. (2010) documented 56 species used for 60 medicinal formulations.

Medicinal plants are widely used to cure minor diseases like common cold, cough, fever, cuts and burns, swelling. Peoples attitude towards medicinal plants is high because of the low availability to hospital services and their faith towards medicinal plants. In our study, we found that people used medicinal plants for diseases like common cold, cough, diarrhea, dysentery, cuts\& burns, skin infections, fungal infections, gastritis, pneumonia, asthma, bleeding gums, kidney stone, sinusitis, ulcer, earache, bowel pain and uterine contraction, purgatives, tumor, piles, ophthalmic disorder, bronchitis heart pain, and jaundice. Their ancestral preaching towards the use of medicinal plants was limited among family members. The use of medicinal plants towards major diseases is found to be low because of slow healing but also few people are attracted to it because of low or no side effects as compared to allelopathic medicine (Jawla et al., 2009). The proportion of the collection of the medicinal plant was high in forests followed by gardens and few are locally available in the market. The low land use in far west Nepal makes more reliable to collect medicinal plant from the field whose use is known (Kunwar et al., 2015). People's high response for the use of the medicinal plant is also due to its easy availability and most of them are found around home gardens making them cost-effective (Joshi et al., 2019). 


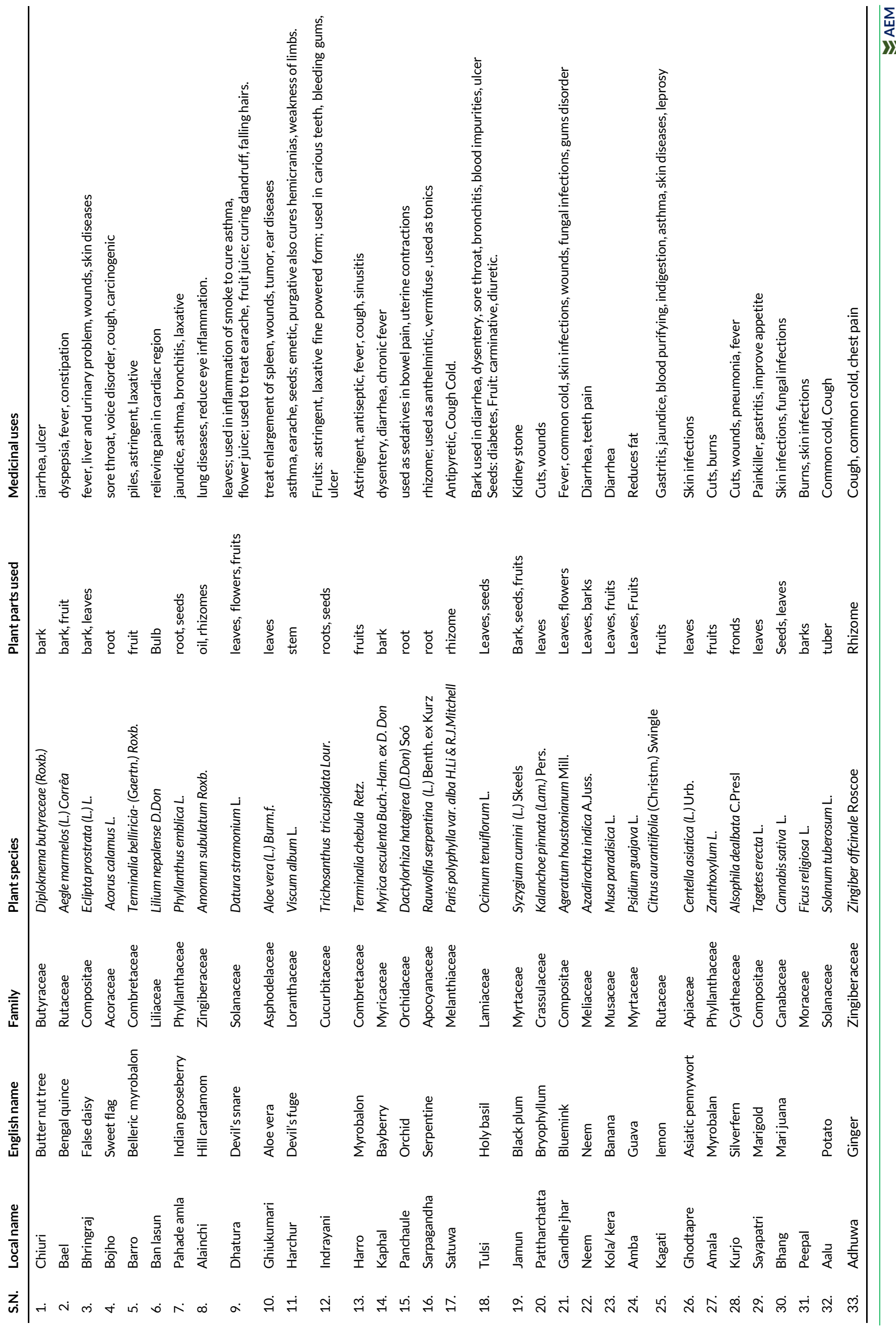




\section{Conclusion}

Medicinal plants are the basics for the household treatment of minor and some of the major diseases. The study showed the direct relationship of households with the use of medicinal plants. By the use of medicinal plants, $92 \%$ of the respondents were satisfied. $76 \%$ of the collected medicinal plants from gardens and $22 \%$ from forests and $2 \%$ from others like ayurvedalaya. A total of 33 medicinal plants were documented to cure 40 ailments. The majority of the medicinal plants collected were found to be used for diseases like fever, diarrhea, cuts and burns, gastritis, heart pain, chest pain, a painkiller. Also, the uses of medicinal plants were reported against diseases like ulcer, diabetes, laxative, dyspepsia, anxiety, gum bleeding, jaundice, pneumonia, asthma, cancer and so on. The use of a single medicinal plant for multiple diseases increases the value of medicinal plants and an effective strategy should be adopted for exploring the use of it. Also, the lack of training related to medicinal plants in the study area showed less knowledge on the conservation of plants and their effective use and propagation. Thus, the concerned government/ non-government body should take effective action for exploring the use of medicinal plants.

Open Access: This is an open access article distributed under the terms of the Creative Commons Attribution 4.0 License, which permits unrestricted use, distribution, and reproduction in any medium, provided the original author(s) if the sources are credited.

\section{REFERENCES}

Acharya, R. (2012). Ethnobotanical study of medicinal plants of Resunga Hill used by Magar community of Badagaun VDC, Gulmi district, Nepal. Scientific World, 10 (10): 54-65, https://doi.org/10.3126/sw.v10i10.6863

Acharya, R. and Acharya, K.P. (2009). Ethnobotanical study of medicinal plants used by Tharu community of Parroha VDC, Rupandehi district, Nepal. Scientific World, 7 (7): 80-84, https://doi.org/10.3126/sw.v7i7.3832

Ajayi, O.O., Catherine, E.S., Carlson, B. and Farid, S. (2005). Designing Household Survey Samples: Practical Guidelines. United Nations. Series F No.98.

Bhattarai, K.R. and Ghimire, M. (2006). Commercially important medicinal and aromatic plants of Nepal and their distribution pattern and conservation measure along the elevation gradient of the Himalayas. Banko Janakari, 16 (1): 3-13, https://doi.org/10.3126/banko.v16i1.357

Ghimire, S.K., Awasthi, B., Rana, S., Rana, H.K., Bhattarai, R. and Pyakurel, D. (2016).
Export of medicinal and aromatic plant materials from Nepal. Botanica Orientalis: Journal of Plant Science, 10: 24-32, https://doi.org/10.3126/botor.v10i0.21020

IUCN (2000). National Register of Medicinal Plants. Kathmandu: IUCN Nepal.

Jawla, S., Gupta, A.K., Singla, R. and Gupta, V. (2009). General awareness and relative popularity of allopathic, ayurvedic and homeopathic systems. Journal of Chemical and Pharmaceutical Research, 1: 105-112.

Joshi, A., Kalauni, D. and Bhattarai, S. (2018). Survey on usage of medicinal plants: a case from Chitwan district of Nepal. SAARC Journal of Agriculture, 16 (2): 129-141, https://doi.org/10.3329/sja.v16i2.40265

Kunwar, R.M., Acharya, R.P., Chowdhary, C.L. and Bussmann, R.W. (2015). Medicinal plant dynamics in indigenous medicines in far west Nepal. Journal of Ethnopharmacology, 163: 210-219, https://doi.org/10.1016/j.jep.2015.01.035

Kunwar, R.M., Shrestha, K.P. and Bussmann, R.W. (2010). Traditional herbal medicine in. Far-west Nepal: A pharmacological appraisal. Journal of Ethnobiology and Ethnomedicine, 6, https://doi.org/10.1186/1746-4269-6-35

Kunwar, RM. and Bussmann, R.W. (2009). Medicinal, aromatic and dye plants of Baitadi and Darchula districts, Nepal Himalaya: status, uses and management In Biodiversity at and Natura usstattung in Himalaya III. Edited by: Hartmann M, Weipert Journal of Naturekunde Museum, Erfurt, Germany 2009: 43-49.

Luitel, D.R., Rokaya, M.B., Timsina, B. and Münzbergová, Z. (2014). Medicinal plants used by the Tamang community in the Makawanpur district of central Nepal. Journal of Ethnobiology and Ethnomedicine, 10 (5): 1-11, https://doi.org/10.1186/1746-4269-10-5

Maciel, M., Pinto, A.C., Veiga Jr., Valdir F., Grynberg, N.F. and Echevarria, A. (2002). Plantas medicinais: a necessidade de estudos multidisciplinares. Química Nova, 25 (3): 429-438, https://dx.doi.org/10.1590/S010040422002000300016

Manandhar, N.P. (2002). Plants and people of Nepal. Timber Press Portland, Oregon USA; pp. 599.

MoAD. (2017). The State of Nepal's Biodiversity for Food and Agriculture. Kathmandu: Ministry of Agriculture Development.

Pandey, P. (1961). Distribution of medicinal plants of Nepal. Symposium on Medicinal Plants, pp. 15-61. Ceylon

Rai, S.K. (2004). Medicinal plants used by Meche people of Jhapa district, eastern Nepal. Our nature, 2 (1): 27-32.

Rajbhandari, T.K., Joshi, N.R., Shrestha, T., Joshi, S.K.G. and Acharya, B. (1995). Medicinal plants of Nepal for Ayurvedic Drugs Government of Nepal, Department of Plant Resources, Thapathali, Kathmandu: pp. 387.

Rokaya, M.B., Münzbergová, Z. and Timsina, B. (2010). Ethnobotanical study of medicinal plants from the Humla district of western Nepal. Journal of Ethnopharmacology, 130 (3), 485-504, https://doi.org/10.1016/ j.jep.2010.05.036

Silva, N.C.C. and Fernandes, A. (2010). Biological properties of medicinal plants: a review of their antimicrobial activity. Journal of venomous animals and toxins including tropical diseases, 16 (3): 402-413.

Singh, A.G. and Kumar, A. (2017). Ethnomedicinal aspects of climbing plants of Palpa district, Nepal.

Thapa, S. (2019). Chiuri: A review on its multipurpose use in Nepal. International Journal of Agriculture and Environmental Research, 5 (4): 527-538. 